Man and Nature

L'homme et la nature

\title{
The Revolt of the Wuerttemberg Estates, 1764-1770
}

\section{Helen P. Liebel-Weckowicz}

Volume 2, 1984

URI : https://id.erudit.org/iderudit/1011816ar

DOI : https://doi.org/10.7202/1011816ar

Aller au sommaire du numéro

Éditeur(s)

Canadian Society for Eighteenth-Century Studies / Société canadienne d'étude du dix-huitième siècle

ISSN

0824-3298 (imprimé)

1927-8810 (numérique)

Découvrir la revue

Citer cet article

Liebel-Weckowicz, H. P. (1984). The Revolt of the Wuerttemberg Estates, 1764-1770. Man and Nature / L'homme et la nature, 2, 109-120.

https://doi.org/10.7202/1011816ar
Résumé de l'article

Les États Généraux (Landtag) du Wuerttemberg ont toléré la taxation inconstitutionnellement élevée qu'a imposé le duc Charles Eugène pendant la guerre de Sept Ans. Par contre ils se sont opposés à sa tentative d'introduire unilatéralement un nouveau système fiscal en temps de paix. L'issue finale de longues négociations apportait aux États Généraux non seulement le droit de percevoir des impôts mais aussi un droit de regard sur le budget ainsi que son administration.
Copyright @ Canadian Society for Eighteenth-Century Studies / Société canadienne d'étude du dix-huitième siècle, 1984
Ce document est protégé par la loi sur le droit d'auteur. L'utilisation des services d’Érudit (y compris la reproduction) est assujettie à sa politique d'utilisation que vous pouvez consulter en ligne.

https://apropos.erudit.org/fr/usagers/politique-dutilisation/ 
THE REVOLT OF THE WUERTTEMBERG ESTATES,

$1764-1770$.

Helen P. Liebel-Weckowicz

More than any other member state of the Holy Roman Empire of the German nation, the Duchy of Wuerttemberg had a parliament dominated by the bourgeoisie. The aristocracy had successfully seceded during the Reformation, and the established Protestant church was also dominated by an elite group of bourgeois families.l Its prelates sat in the estates-general (Landtag) along with the delegates from the towns and counties elected by the town-and-county assemblies. The parliament also had control of the power of the purse, and all taxes imposed had to be presented to the diet for approval. On the whole, the estates were reluctant to approve any appropriations beyond those set by negotiated compacts. These then had the effect of a constitutional commitment. The rebellion of 1764 in fact broke out over the question of the duke's unilaterally decreed property tax of 6 March 1764.

In the eighteenth century, the rise of enlightened absolutism produced a two-fold change in the traditional parliamentary system. The delegates were elected by county assemblies representing the villages as well as the towns, but the estates-general (Landtag) seldom met. In its place two executive councils, the Great Committee and the Small Committee, negotiated with the privy council and the duke to determine the repartition of taxes and such other business of state which fell within the provenance of the parliament. ${ }^{2}$ In the eighteenth century the parliament had 84 seats. Of these 72 represented secular districts. Ten of the latter even represented completely rural districts and sometimes sent servile peasants as delegates. The twelve ecclesiastical seats were represented by prelates who 
could choose to ignore the petitions of their subjects or not, although county assemblies did exist in the prelates' districts. 3 Between 1737 and 1763 no Landtag was convened, but the 1763 diet became Wuerttemberg's "Long Parliament," and remained in plenary session (with interruptions) for seven years. Membership in the Long Parliament had changed somewhat. There were 68 secular seats with most districts sending only one delegate. The three major cities of Stuttgart, Tübingen, and Ludwigsburg, all of which served as government towns, had two each. Three of fourteen prelates were absent for reasons of health. In sum, 84 persons participated.

Wuerttemberg on the whole was at that time as densely populated as France, and its economy suffered from a decline of the centuries-old wine trade. Both its prosperous linen and woolen cloth industries were depressed relative to their importance earlier in the century. The Nagold River industrial region in particular was to suffer from a weak economy for the next two decades. But during the Seven Years' War, cotton printing had grown in the Sulz area and had come to employ over one thousand rural workers. Most of the towns traded in agricultural goods and most of the land was farmed in small parcels held as leaseholds for which an annual quitrent ( $\underline{\text { Zins }}$ ) was paid. Many craftsmen were also leaseholders, holding tracts of arable land in the fields surrounding the towns. Thus the strong representation of the towns to a large extent included rural interests. The Duchy of Wuerttemberg had remained Protestant since the Reformation. The revenues from the properties of the Roman church, which had been nationalized during the sixteenth century, financed the salaries of the clergy and the costs of the educational system from the co-educational German-language elementary schools to the training of clergymen at the University of Tübingen. Generous scholarships also enabled talented young men to attend both the Latin grammar schools and the university. In 1733, however, upon the death of the childless Eberhard Louis, the succession of his Roman Catholic cousin, General Charles Alexander (1684-1737), a friend of Prince Eugene of Savoy and an Austrian field marshal, caused some concern for the stability of the Protestant Establishment. However, the new ruler confirmed all religious freedoms and the constitution of the land, and gained considerable approval for his attacks on the scandalous nepotism of the previous regime. The cost of the War of the Polish Succession and various attempts to by-pass the parliament in order to raise revenues resulted in new scandals, and enough excitement ${ }_{5}$ to bring on the sudden death, probably of a coronary, of Charles Alexander. ${ }^{5}$

The later rebellion of the estates is in part the result of the domination they achieved during the regency period which followed. At the accession of the minor Duke Charles Eugene (1728-1793), the regency was shared by two uncles, the last of whom, Charles Frederick of Wuerttemberg-Oels was asked to step down against a gift from the estates of 10,000 gulden and a pension of 3000 gulden a year. ${ }^{6}$ During the following decade, the parliament's executive committee under the iron leadership of the directing minister of state, Friedrich August von Hardenberg, had a firm control of the government and of all policy-making. 7 However, in 1744, Frederick the Great of Prussia intervened, and had the young prince declared of age. Not only had he spent several years at the Berlin court, but he had been engaged to Frederick's niece, the daughter of the king's favorite sister, Wilhelmine of Bayreuth. 8 
Almost from the first year of his reign, Charles Eugene tried to increase the size of the army. 9 With the dismissal of Hardenberg in 1755 , the duke tried to intervene in all government business himself, most of the time asking for monetary payments to his own hands. By 1756, when the Seven Years' War broke out, the officials of the parliament were already being urged by their famous Consulent, Johann Jakob Moser, the most prominent jurist in the old Reich, to seek better protection for the constitution against the growing authoritarianism of the duke. ${ }^{10}$ When the Reich declared war on Frederick of Prussia on 17 January 1757, the duke, as commander-in-chief of the Swabian Circle contingent, was required to raise 1461 infantry and 267 dragoons as prescribed in the constitution. However, these as well as other Wuerttemberg recruits, 6000 in all, had been sold to the French by subsidy treaty. The result was a conscription to raise the circle contingent. Public opinion resented the war and sympathized with the Prussians, whose king posed as a second Gustav Adolphus and saviour of Protestantism. His recruiting officers also made forays into the duchy in order to bring Wuerttembergers into his armies. Although the constitution prescribed proper recruitment and forbade conscription as such, the duke resorted to brutal impressments to meet his quotas. Able bodied men were seized in their beds at night and at church on Sundays. On 20 June 1757, the first of three mutinies broke out. The hostility to the draft continued throughout the war, but organized political resistance became possible only in 1763-64, when the war ended.

The duke's ambitions were to some extent supported by Vienna. Maria Theresa and Prince Colloredo, the imperial vice chancellor, recommended Count Samuel von Montmartin to the Stuttgart court in 1758. As prime minister he encouraged the duke's absolutism and his ambition to secure an electoral seat (Kurhut), and even to annex such important towns as Ulm and Nürnberg. 12 Backed by Montmartin, Charles Eugene collected taxes unilaterally and tried to wrest more money from the parliamentary Great Committee. The estates executive, however, resisted the duke's demands for a larger defense allocation, so that the duke sent his troops to seize all the parliamentary treasure deposits in January, 1759. Even before this act of violence was committed, Moser had suggested that the parliament begin to negotiate with foreign powers so that the Wuerttemberg grievances could be made an issue at the forthcoming peace congress. Two of the powers who had guaranteed the constitution and the religious freedoms in 1733, Hanover and Brandenburg-Prussia, were at war with the Reich. The emperor was the duke's ally. Through his eldest son, Frederick Charles von Moser, then a minister in Hesse-Darmstadt, but also one of the Hanoverian agents in the empire during the war, Johann Jakob Moser wanted to begin diplomatic negotiations between the Wuerttemberg diet and potential allies in the empire, most particularly with Hanover. Suspicious of these moves, and probably fearful of a Prussian military intervention which might have put his brother Frederick Eugene, a Prussian general, on the throne, Charles had Moser arrested on 12 July 1759. Imprisoned without trial and without even the right to use pen or paper, Moser's case was made an issue during the election of Joseph II in 1764 and eventually his release was secured. This was after some five years of harsh imprisonment and only after Frederick the Great and George III had interceded on his behalf with Francis I during the election negotiations. 13 As his most recent biographer, Rürup, has commented, "Moser enjoyed a reputation in the entire Reich as a defender of the constitutional rights of the land against arbitrary absolutism." 14 
Mutiny and desertion played their role during the war. Beginning about 1757, a large part of the duke's conscript army deserted en route to the Silesian front. Many of those recaptured were executed. The imperial armies were badly defeated and the Wuerttemberg casualties were high. By the end of the winter only 1900 of the 6000 troops remained. Military tax collections reached a peak of 1.6 million gulden only in 1760 , however, and represented a sizeable increase over the old ceiling of 460,000 gulden. The largest army the duke gathered numbered 12,000 men and was employed at the Elbe river front. Again, Charles Eugene lost heavily on 25 October 1760 at Magdeburg to Prussian forces commanded by his own brother, Frederick Eugene. Thereafter the Wuerttemberg forces were kept at home, although few troop reductions took place.

Although the revenues collected for military costs did not reach the 1760 level again, annual military revenues to the end of the war varied between a low of 1.2 million gulden and a high of 1.56 million for $1761 / 62$. The parliament later estimated and in part demanded restitution for many of the military revenues collected for the period between 1757 and 1763, which amounted to $8,788,836$ gulden. 16 The war was paid for by monies extracted from the estates, from the tax arrears, from loans on the salt monopoly, from forced loans exacted from officials, from exactions of fourage and labor and trucking services from the peasantry, and by confiscation of local grain stores. The following table shows that the total sums declined towards the end of the war. Yet the percentage of monies collected over and above the constitutional appropriation of 460,000 gulden remained consistently high:

TABLE I. 17

\author{
Totals Collected per \\ annum
}

$\begin{array}{lr}1757 / 58 & 530,000 \mathrm{fl} . \\ 1758 / 59 & 1,107,384 \\ 1759 / 60 & 1,683,077 \\ 1760 / 61 & 1,371,159 \\ 1761 / 62 & 1,568,902 \\ 1762 / 63 & 1,322,180 \\ 1763 & 1,206,131\end{array}$

$\%$ increase or decrease p.a.
\% over constitutional limit
$+15 \%$

$+141 \%$

$+265 \%$

$+198 \%$

$+241 \%$

$+187 \%$

$+162 \%$

Although the war was all but over at the end of 1762, the duke announced a plan to keep a peacetime army of 10,000 men and to raise the parliament's contribution from the old ceiling of 430,000 gulden to a new budget level of $1,621,868$ gulden. He argued that the previous organization was no longer completely applicable because the times had changed. Further, all other laws, compacts, and regulations had to give way before the new goals. As soon as the defense and survival of the country were called 
into question, the obligations of the subjects could no longer be constitutionally limited. It was then the subject's sole duty to contribute to the welfare and the good of the state, to carry the burden with "common shoulders." The duke assured his diet that he had maturely reflected on the military needs and that his General Military Plan, effective 1 January 1763, had been estimated against the ability of the country to pay-"Krafften des Landes." The argument of the preamble pointed out that there had been a sizeable increase in the number of regiments since 1744. If we take the four basic regiments which made up the total ducal and circle contingents, we find that the budget that year was 273,644 gulden, well under the ceiling. In the 1763 plan the same four regiments and artillery cost only 307,568 gulden, but since the number of regiments had been increased, that sum made up only $19 \%$ of the total budget planned. It is interesting to note that the amount to be spent on the circle infantry was to be reduced from the 109,620 gulden contribution of 1744 to only 48,649 gulden in 1763. The duke's own body guard, however, was raised from 17,064 gulden to 55,125 gulden and his footguards from 90,153 gulden to 163,886 gulden. On the whole the new budget had 40 different expenditure items compared with only five in the 1744 budget. 18 The total sum demanded for the 1763 budget was $1,621,868$ gulden p.a., an increase of $150 \%$ over the old peacetime figure. The Small Committee refused the plan, howeger, and the duke continued to collect a monthly military tax unilaterally.

The 1763 budget statistics enable us to compare the military salary scales with those of the duke's court entertainers, dancers, and opera singers. This, it turns out, shows that the annual wage of Ludwigsburg manual laborers was only 50 gulden. Meat and ammunition for the army was estimated at 60,000 gulden p.a. Maintenance of the artillery and the armory cost 8000 gulden p.a. The military salaries were not remarkably high either; the 58 general staff of ficiers averaged 1118 gulden p.a. Some 1423 footguards averaged 115 gulden while 1569 field grenadiers averaged only 101 gulden a year. Soldiers in special cavalry or dragoons regiments had an annual salary range which was higher than that of the foot soldiers and averaged beffreen 197 and 330 gulden, although artillerymen averaged only 139 gulden.

Although the list of salaries of court performers which the parliament submitted to the Aulic Council in 1765 does not give the dates, one can suppose that these fall in the early or mid 1760s. The contrast with the military budget is startling. Some 88 persons of the court theatre involved in production, repairs, and costume manufacture, and including handy-men as well as the comedians and dancers, cost 127,540 gulden a year to maintain. The breakdown is even more interesting. Twenty comedians averaged an annual income of 1800 gulden, and 56 dancers, 1397 gulden; but the theatre staff, which included the lower paid handymen, only 1108 gulden. This was on the whole more than the salary of any general staff officer and very nearly the average income of the highest salaried judges and privy councillors in many of the small German states. 21 Charles Eugene's generosity knew no bounds, for he also paid his music director Niccolo Jomelli (employed in 1753) an annual salary of 3000 gulden, the same as the regent's retirement pay. 22 The building spree that went along with it also served to incite the public and estates; new opera houses, theatres for Ludwigsburg, new palaces and summer residences, carnivals and feasts. The costs were borne not out of the duke's private income of 700,000 gulden a year, but out of the funds of the district 
administrations, the district wine cellars, the treasury of the country, and the revenues 3 of the church lands which ordinarily paid for the education system.

Once peace was actually signed on 15 February 1763, the parliament at once protested this oppressive economy. On 11 March, the estates executive demanded that the duke convene a full diet as soon as possible. With the war over, they were also free to seek the aid of their foreign guarantors, Frederick of Prussia, George III, and Frederick V of Denmark. Since it was the church's lands which had been taxed and also alienated, the guarantee of the religious establishment had been called into question. But since the emperor had also sworn to protect their religious freedoms, the 2 frecu- $^{-}$ tive committee also decided to send an appeal to Vienna on 11 March.

Charles Eugene evidently had no intention of negotiating with the estates, believing that he had Vienna's full support to continue an absolutist policy. In order to raise funds to meet his extraordinary expenses he began the sale of public offices. This practice of Dienst Verkauf began in 1761 with sales to only 36 persons. The statistics compiled by the estates on this subject are revealing. The fewer the offices sold, the higher the average price. During 1762 to 1764 hundreds of offices were sold to the highest bidder. The peak year was 1764 when 846 persons bought them at an average price of 261 gulden. In 1766, when only 51 persons bought, the average price was 1618 gulden. During the entire reign of Charles Eugene down to 1793, the net revenue from sale of offices was 1,099,941 gulden. Sales trickled to only a few a year after the duke compromised with the estates in 1767. Between 1762 and 1766, some 1822 persons bought offices for 758,441 gulden. 25 As a result of these practices, however, public opposition grew so intense that the estates was able to use the rebellion of 1764 to reduce the sale of offices from 846 in 1764 to only 80 in 1765 .

The first full session of parliament to meet in Charles Eugene's reign convened in the fall of 1763. It agreed to adjourn on 13 October, after only two weeks of futile negotiation. During the brief session the members refused to submit to any of the duke's proposals until he first recognized the petitions of grievance and desisted from further violation of the constitution. As a result the government faced a new financial crisis. Under Montmartin's influence a ducal property tax (Vermögens Steuer) was to be decreed on 6 March 1764. It was this which provoked the revolt not only of the diet but of town and county assemblies and officials. Why?

Grube, the historian of the parliament, even thought the new tax could have relieved the tax burdens of the poor if it had replaced the ordinary repartition and had been used to raise the fixed military appropriation of 460,000 gulden. But it was intended to replace the monthly tax which the diet had repealed, in order to raise the sum required for the new military plan, that is, 1.6 million gulden. The new tax no longer exempted philanthropic institutions and the estates immediately perceived that it was aimed at instituting ducal absolutism and crushing the parliament's power of the purse. Not only was it to be proclaimed unilaterally, but the revenues collected were to go to the war department (Kriegskasse) and not to the parliament's treasury (Landschaftskasse).27 
The historians who have commented on this tax have failed to assess the real impact it was to have on the economy. The Steuer Reglement of 6 March 1764 created twelve different tax levels for twelve corresponding classes of property assessed at real capital value. That is, it did not tax income from investments, it taxed capital as such. Further, it was the total property, personal and other, including all personal jewelry of the family, which was to be taxed. For the largely agricultural population this meant an assessment of all farming capital including all animals and tools, all wine stocks, all food stores and inventories and even all salaries. But salary was to be capitalized at twice its annual worth. In addition, once the estimated value had been determined, the wife paid the same amount as the husband who was registered in that property class. The master also paid for his journeymen and apprentices, servants, and children, in short, for the entire craftsman's workshop and household. To illustrate. If the capital worth was assessed at 1600 gulden, the taxpayer was put in class VII, for which the tax listed was 4 gulden. However, the assessed owner also paid another 4 gulden for his wife, 24 Kreuzer for each of four children, and a similar sum for his four journeymen, or a total of 11 gulden 54 Kreuzer for ten persons. The expenses of a household of ten persons living on an income of 1600 gulden capital was likely not higher than 600 gulden. In a bad year, possibly less. A sum of 600 gulden distributed over ten persons averaged 60 gulden each. The 11 gulden tax would be added to others, including various consumer taxes and excises. In themselves the tax rates were not high. When seen against the heavy burden of indebtedness imposed by the wartime tax policies of the duke, they proved to be the last straw for most communities.

Some of the ducal officials approved the new measure which was announced to the district officials in a secret meeting. J.C. Commerell of Kircheim praised it in biblical phrases: "This is the day that the Lord hath made; let us rejoice. . ." and was promoted for his enthusiasm to the central government and later to the privy council.

At the same time that the tax edict was announced, the electors of the empire were intent upon negotiating the election of the emperor's eldest son, Joseph, as his father's designated heir or "King of the Romans." The Prussian ambassadors, and to some extent the Hanoverian, did not hold up the election because of the Wuerttemberg grievances. But the behind the scenes diplomacy seems to have effected a compromise from Francis I, who agreed to urge the duke to curtail his expenditures and to try to resolve his differences with the estates. Since Wuerttemberg had its own negotiators in Frankfurt, they must have known that a petition to the emperor would be graciously received and that the desired action might be effected. The emperor himself realized that his political position in the peacetime empire depended on satisfying the two strong Protestant electors in the north, George III and Frederick the Great. Both had guaranteed the Wuerttemberg constitution and the religious establishment.

A few weeks after Joseph II's coronation in Frankfurt, the Stuttgart diet sent a petition to Francis I dated 29 May 1764. In it they asked the emperor to declare a protectorio for the estates, and to ask Charles Eugene to cease his enforced collection of taxes, his execution of decrees by military force, and other violations of the constitution. The duke was to 
be prevented from imposing a military contribution or the property tax and was to halt all measures previously used to enforce these exactions. 31 That by the end of May at least two towns had already refused to submit to the illegal tax is clear from the list of appendices sent to Vienna with the request. These were Balingen and Pfüllingen. The reports sent in from the counties to the Small Committee in Stuttgart show more resistance and the use of military force. The earliest protest is dated 4 April, Rosenfeld. Some other towns like Stuttgart itself ( 3 May) merely objected to the contradictions in the new tax and insisted that under any circumstances the bonds floated by the parliament to save the state and other capital of the estates had to remain exempt from any property tax. Pfüllingen had revolted before 28 May, the date of its report. Almost all citizens had refused to accept the tax forms. Troops had been sent in. The town magistrate argued that complete financial exhaustion was the reason for the refusal. The number of troops sent to the smaller towns seems to have consisted of one or two officers and perhaps twenty-four to thirty men. Even the rural districts found the tax impossible. Marbach, Schiller's home town, reported that none of the farmers could possibly raise the money for such a tax (30 June). In the depressed industrial district of Wildberg, troops were reported on $16 \mathrm{July}$, and the townsmen complained that it was the enormous poverty of the population and the general inability of anyone to give aid in cash or victuals which made it impossible for them to accept the tax: ". . . most of the inhabitants of this town and country suffer the worst hunger, 3 and often cannot even enjoy a little bit of bread. They live on sour milk." 32

The most serious opposition came in Tübingen, which was the seat of the appellate court and the university. There too, the duke's own district administrator joined the rebels. Johann Ludwig Huber (1723-1800) was also the duchy's leading poet and wrote a highly literate autobiography in which he described his rebellion. 33 Huber had been dismissed and arrested on 12 June. Despite further threats and intimidations from the military occupation, the magistrate and council held firm. Interestingly enough, the Tübingen resistance was not to the property tax but to a new monthly military tax. Huber's argument had been that his oath to uphold the constitution had prevented him from submitting to the ducal order. Later, when some of the Tübingen dissidents were brought before the duke, they argued that their obligation to uphold the constitution of the state impelled their actions. The duke is alleged to have burst out, "What, the state!

The news that Charles Eugene was ignoring the suggestions made to him at Frankfurt and that he had sent troops to Tübingen in June to enforce his decree shocked the ambassadors to the Regensburg Reichstag. It was believed that the three royal courts could not now possibly succeed in restoring the constitution even if they intervened. But Francis I proved true to his word. The Aulic Council in Vienna decided in favor of the protectorio on 6 september 1764. In the imperial edict, the emperor ordered the convocation of the estates, the hearing of all grievances, and a halt to the military collection of taxes. 35

The duke refused to heed and the case was then taken to the Aulic Council. The special delegation sent by the parliament to negotiate a settlement left a massive four volume diary written in diverse hands. 
Hostile as the imperial judges were in Vienna, the enormous number of papers brought by the estates overcame the antagonism. Soon the judges saw the extent to which the financial abuses were destroying the economy. The Aulic Council itself then appointed a special commission to deal with the case. Its meetings were irregular, but the first session was held on 16 November 1765. The chairman of the commission, Count von Ueberacker, opened the first session with pointed remarks about public opinion in Germany, which he claimed had been aroused by the grievances which the estates had against the duke. 36 The negotiations proceeded only at a snail's pace, however, until 1768 when Frederick the Great's threatened alliance with Russia provoked a new round of activity in Vienna. The Aulic Council had already approved the preliminary agreement which reaffirmed the constitution first and foremost in February, 1767.

Frederick the Great supported a secret agreement with the duke's youngest brother and likely heir, Frederick Eugene. Married to the king's niece, he now promised to raise his sons as Protestants. Joseph II meanwhile had the Wuerttemberg case on the agenda when he met Frederick at Neisse in August 1769. Both rulers agreed to see to it that the affair be settled soon. In return Frederick promised to keep the neutrality of the empire in case of war between England and France. As a result, the Erbvergleich or Agreement of Settlement was signed in Vienna on 19 December 1769. It was ratified by the duke on 1 January, and by the parliament on 27 February 1770. The two contending religious parties of the Reich were once more in equilibrium.

However, the duke did not immediately change his policies. On 22 October 1770, the parliament was once more complaining to the Aulic Council about the exaftions, impressments, labor services, and extravagant court expenditures.

Joseph II once more supported the parliament and ordered an implementation of the agreement in November. He himself confirmed the agreement only on 24 December 1770 after the diet had appropriated another 400,000 gulden. Also, the emperor managed to secure all possible Austrian rights to the future succession in case the Wuerttemberg line died out. In that event, none of the compacts were to be binding. Even the legal fees charged for issuing the confirmation, the emperor's pergament, the gold seal, etc. all cost 15,000 gulden. Finally, the stipulation that all accounts be investigated before they were settled led to a long drawn out negotiation which ended only in 1776. By that time over 1 million gulden in interest on the state debt had to be paid. Not until 11 February 1780 did the duke sign a penultimate agreement, in part urged by his two brothers, who now feared the complete financial ruin of the duchy would occur before they ever came to power unless some steps were taken immediately. Since Prince Louis was responsible for that, he was able to secure the diet's agreement to pay him 70,000 gulden a year for six years in order to pay of $\mathrm{f}$ his debts.

The final achievement of the old estates before the French Revolution was a first break-through to the modern right of parliament not only to control the appropriations of taxes but to oversee the management of the state budget. This was a direct result of the 1764 rebellion. It had cost the taxpayer dearly, for the amount of money that changed hands seemed 
sometimes as high as the duke's own spendings. In spite of that, the Wuerttemberg parliament was neither as moribund as German historians have alleged, nor did it lock itself into the narrow provincial practice of following the self interest of the few who were represented in that privileged and corporate body. The first steps towards a modern, viable form of parliamentary government had already been taken by 1780.38

University of Alberta

Notes

1 Helen P. Liebel, "The Bourgeoisie in Southwestern Germany, 1500-1789: A Rising Class?" International Review of Social History, 10, pt. 2 (1955), 283-307.

Walter Grube, Der Stuttgarter Landtag, 1457-1957 (Stuttgart, 1957), pp. $399 \mathrm{ff}$.

3 Ibid., 404-05. The prelates' districts (Stadt-und Amt in the secular districts) were called Klosteraemter.

Ibid., 433 and Abbildung 19.

Biographisches Woerterbuch zur Deutschen Geschichte, I, 1444-45; F.L. Carsten, Princes and Parliaments in Germany from the Fifteenth to the Eighteenth Century (Oxford, 1959), pp. 123-128.

Albert Eugen Adam, "Herzog Karl und die Landschaft," Herzog Karl Eugen von Wuerttemberg und seine Zeit, ed. Wuertt. Geschichts-und Altertums-Verein, 2 vols. (Stuttgart, 1905), I, 194. Landschafft was the name given to the estates as such, while the meetings or full sessions were called Landtage.

Friedrich August von Hardenberg. Ein kleinstaatlicher Minister des 18. Jahrhunderts (Leipzig, 1877).

BWDG, II, 1446.

9 A.E. Adam, "Landschaft," p. 196; Karl Pfaff, Peter Lahnstein, Wuerttembergs geliebte Herren (Stuttgart, 1967), pp. 65-66.

A.E. Adam, "Landschaft," p. 207.

11 Ibid., 209-210; Albert Eugen Adam, Johann Jakob Moser als Wuerttembergischer Landschaftskonsulent 1751-1771 (Stuttgart, 1887), pp. 30-34. 
13 Reinhard Rürup, Johann Jakob Moser. Pietismus und Reform (Wiesbaden, 1965), pp. 159-168; August Schmid, ed. Das Leben Johann Jakob Mosers. Aus seiner Selbstbiographie (Stuttgart, 1868), p. 278 .

14 Rürup, p. 168.

15 Albert Pfister, "Das Militärwesen," KE u. Zeit, I, 126-219, 132. HStA, Stuttgart. A 34 Landschaftsstreit. Bü 1ll/nr. 6 "Consignation der Berechung ...zur Kriegs Casse..von dem Lande eingetrieben.."

16 HȘtA, Stgt. A 34 Bü 11l/nr. 6 .

17 Ibid.

18 Sammlung der merkwürdigsten Staats-Schriften. Verhandlungen und Recesse, welche bey den würklich obwaltenden Strittigkeiten Sr. Herzogl. Durchlaucht des regierenden Herrn Herzogs zu Würtemberg und Dero Landständen gewechselt worden. $(4$ vols. Frankfurt \& Leipzig, 1766), I, 33 for 1744 budget and 85 ff. for 1763 budget. (This work hereafter cited as Strittigkeiten.) A copy of the 1763 budget was also included in the papers given to the Aulic Council. See HHStA, Wien. RHR Den. rec. 1471. General Militair Plan. In 1735 the duke's father, Charles Alexander, had forced the Large Committee to approve an army of 12,100 and a military grant of 480,000 gulden. In connection with this plan there had been an attempt to agree to an arrest of the leaders of the estates. All of these ended when Alexander died suddenly, on 12 March 1737 (likely of "foul play") (Carsten, pp. $125-128)$.

19 Grube, p. 431; Adam, "Landschaft," p. 233.

20 HHSStA, Wien. RHR Den rec. 1471. General Militair Plan 1763, items 1, $22,2-21,32,39$. The clergy had a slightly higher salary range. In 1758 the average for 660 clerical posts was between 150 and 600 gulden a year. Liebel, "Bourgeoisie," p. 303, n. 3.

21 HHStA, Wien. RHR Den. rec. 1471, "Comoedien-Etat und Consignation derer Tänzer, welche sich gegenwärtig in Herzoglich Wuerttemberg Diensten und Besoldungen befinden." Also the discussion in Helen P. Liebel, Englightened Bureaucracy versus Enlightened Despotism in Baden, 1750-1792. American Philosophical Society, Transactions, vol. 55/5 (Philadelphia, 1965), passim.

Rudolf Krauss, "Das Theaer," KE U. Zeit, I, 495.

Ibid., $497 \mathrm{ff}$. La Vérité Telle qu'elle est contre La Pure Vérité (Stuttgart, 1765) describes numerous festivals.

A.E. Adam, "Landschaft," pp. 234-235.

Wuerttembergische Landesbibliothek. Stuttgart. Cod. Hist. 651, Kaps. 8. Dienst Verkauf von 1761-1793. 
26 Ibid. Lorenz Wittleder, a former tanner, had joined Wuerttemberg services after a stint in the Prussian army. He rose rapidly and became head of the church administrative council (Kirchen Rat) and was largely responsible for the corrupt practices in the Dienst Verkauf. See Georg Jakob Gegel, Beleuchtung einer Regierungsperiode des gegenwärtigen Regent Wuerttembergs (Stuttgart, 1789), pp. $190 \mathrm{ff}$.

27 Grube, p. 436.

28 Strittigkeiten, I, 145, $184 \mathrm{f}$.

29 A.E. Adam, Moser, p. 79.

30 Helen P. Liebel, "The Election of Joseph II and the Challenge to Imperial Unity in Germany, 1763-64," Canadian Journal of History, 15 (1980), 371-397.

31 HStA, Stuttgart. A 34, Bü $111 / \mathrm{nr} .9$.

32 HStA, Stuttgart. A 34, Bü 105. Section: Lit. SSSSS.

33 Johann Ludwig Huber, Etwas von Meinem Lebenslauf und etwas von meiner Muse auf der Vestung--ein kleiner Beitrag zu der selbst erlebten Geschichte meines Vaterlandes (Stuttgart, 1798), pp. $41 \mathrm{ff}$.

34 Stälin, p. 385; Liebel, "Bourgeoisie," pp. 304-07; A 34, Bü 111/nr. 10.

35 Helen Liebel, "Count J.H.E. von Bernstorff's German Policy and the Balance of Power in Northern Europe, 1764-1772," Third Conference on Baltic Studies in Scandinavia (1977), I, 105-108.

36 HStA, Stuttgart. A 34, Bd. 72, pp. 1-245, $245 \mathrm{ff}$.

37 HHStA, Wien. RHR Den. rec. 1471. Oct. 22, 1770.

38 A.E. Adam, "Landschaft," pp. 271-289. 